\title{
General Partnerships and the Fiduciary Duty in the US Legal System
}

\author{
A general partnership és a bizalmi kötelezettség \\ az Egyesült Államokban
}

\begin{abstract}
The law of fiduciary duty is as old as common law. It is the key element of the law of equity. The agency relationship creates a fiduciary relationship between the parties, which means that the fiduciary (agent) is subject to the direction of the one on whose behalf he acts (principal). This high standard of conduct - in the scope of the agency relationship - has become a separate liability form in the common law countries and has appeared not only in company law but in other parts of civil law as well. This paper presents the development and the basic elements of fiduciary duty in the field of general partnerships.
\end{abstract}

Keywords: fiduciary duty, agency relationship, duty of loyalty, duty of care, general partnership

\begin{abstract}
ABSZTRAKT
Az amerikai társasági jogban bevett, ám az európai és a magyar jogban nem létező bizalmi kötelezettségként (fiduciary duty) nevesített felelösségi forma eredetileg a képviselö és a képviselt viszonyában fennálló egyoldalú kötelezettség, amely kizárólag a képviselő kötelezettsége a megbízója felé. A bizalmi kötelezettség keretében a képviselőnek eljárása során a legmagasabb elvárhatósági mérce alapján kell felelnie a megbízója felé. Ezt a kötelezettséget a bírói gyakorlat töltötte meg tartalommal, és az elmúlt száz évben kiterjesztően alkalmazták gazdasági társaságokban fennálló jogviszonyokra is. A fiduciary duty elsőként a general partnershiphez kapcsolódóan jelent meg, mint a társaság tagjai között fennálló fokozott felelősségi tényállás egymás irányában. A tanulmány az ehhez kapcsolódó esetjoggal és annak következményeivel foglalkozik.
\end{abstract}

Kulcsszavak: bizalmi kötelezettség, képviseleti jogviszony, lojalitás, tagi felelősség

The present paper introduces a liability form that exists in US company law and which has a critical role. This is the fiduciary duty, which is - to the European mind a very strange institution; on the other hand, for an American law professor, the lack of this institution is strange. I will never forget the faces of the students and professors at an American law school when I told them that the fiduciary duty does not exist in our legal system. How can we control the members and the directors of business associations then? - they asked. What is this institution good for? - I asked. I would like to take the opportunity to introduce this legal form of liability in the area of general partnerships.

* Márta Plásztán-Brehószki, PhD, Senior Lecturer, Pázmány Péter Catholic University (Budapest, Hungary) Faculty of Law and Political Sciences; e-mail: plasztanm@gmail.com. 
The fiduciary duty is not a novel legal concept. ${ }^{1}$ The law of fiduciary duty is as old as common law. It is the key element of the law of equity. Historically, the law of trust has made more significant advances than the general law of fiduciary duty, and only recently has fiduciary duty begun to be articulated as a separate form of liability.

All fiduciary relationships are, at some level, contractual. The fiduciary agrees by contract to take on a task and assume fiduciary duties in that task's performance. A party decides to bind another to fiduciary duties because the nature of the task undertaken is such that some degree of trust is required. ${ }^{2}$

The Restatement of the Agency defines agency as a "fiduciary relationship that arises when one person (principal) manifests assent to another person (an agent) that the agent shall act on the principal's behalf and subject to the principal's control, and the agent manifests assent otherwise consents so to act." ${ }^{3}$

Fiduciary means to act in the best interests (on behalf) of the beneficiary. On the other hand, conflict of interest or self-dealing on the part of the fiduciary is not the only necessary element to find a breach of fiduciary duty. ${ }^{4}$

\section{Where does the fiduciary duty come from?}

The agency relationship has two primary sources in the United States of America: the Second and the Third Restatement of Agency. The American Law Institute authored these restatements. They are influential and persuasive in the courts, but they are not binding.

The Second Restatement defines agency as "a fiduciary relation which results from the manifestation of consent by one person to another that the other shall act on his behalf and subject to his control and consent by the other so to act." The principal is the one for whom the action is to be taken, and the agent is the one who is to act.

The agency relationship creates a fiduciary relationship between the parties, which means that the fiduciary (agent) is subject to the direction of the one on whose behalf he acts (principal). ${ }^{6}$

As we can see, the fiduciary duty appears not only in business association law but also in many other law fields. Any person can hold power to act on behalf of another. The person who is holding such a power is a fiduciary and is subject to duties and liabilities with regards to the principal. ${ }^{7}$

${ }^{1}$ Christopher Hanno, 'The other "F" word: Fiduciary Duties, Fiduciary Waivers, and the Delaware Limited Liability Company' (2010) S. Tex. Law Rev. 101, 103.

2 Kelli Alces Williams, 'Debunking the Corporate Fiduciary Myth' (2010) J. Corp. L. 240, 244.

${ }^{3}$ Restatement (Third) of Agency (2006) § 1.01.

${ }^{4}$ Clea Parfitt and Melinda Munro, 'Whose interests are we talking about? : A.(C) v Critchley and developments in the law of the fiduciary duty' (1999) U. Brit. Colum. L. Rev. 199, 200.

${ }^{5}$ Restatement (Second) of Agency (1958) § 1.

${ }^{6}$ Larry E. Ribstein, 'Fencing fiduciary duties' (2011) B.U.L. Rev. 899, 903. "A fiduciary relationship is an agency relationship, but an agency relationship is not necessarily a fiduciary relationship."

${ }^{7}$ Restatement (Second) of Agency (1958) § 21. 


\section{What is a fiduciary duty?}

The agency relationship has the important characteristic of being a fiduciary relationship. It means that the agent is a fiduciary, so the agent is held to a very high standard of conduct when carrying out this mandate for the principal's interests.

The agent's duty is to act loyally and carefully when acting within the scope of the agency. This high standard of conduct within the scope of the agency relationship has become a separate liability form in the common law countries and has appeared not only in business association law, but in other parts of the civil law as well.

For example, in Canada in the Guerin $v$ The Queen case,$^{8}$ where Indian lands were leased to the Crown on terms, and which were later leased by the Crown to a third party on different and less favourable terms than those agreed to by the Indian band, the court found that the Crown owed the band a fiduciary duty that was breached. In the Norberg $v$ Wynrib case ${ }^{9}$ where a doctor provided drugs (painkillers) to Laura Norberg for sexual favours, the court found that their relationship was a fiduciary relationship. Here the court stated: "The essence of a fiduciary relationship is that one party exercises power on behalf of another and pledges himself or herself to act in the best interests of the other."

This shows us that the fiduciary duty can have a very wide range, not only in company law but in other law fields as well.

\section{Who can be a fiduciary?}

This special liability form runs only from the agent to the principal, so it is very important that the principal's duties are not fiduciary in nature.

In business association law, we can see that fiduciary duty runs from the directors to the company and to the members of the company, it also running from the members of a business association to the other members, too. A partnership, a limited partnership, a limited liability company or a corporation can be a principal or an agent in an agency relationship.

In this article I would like to show the main principles of the fiduciary duty in general partnerships. A general partnership ${ }^{10}$ is an association of two or more persons in order to carry out business for profit as co-owners. ${ }^{11}$ So the general partnership exists if the persons agree to the common business for profit, and it is not necessary to incorporate the business form like in most European countries. Sometimes it is not easy to determine whether the partnership exists or not, so $\S 7$ of the Uniform Partnership Act (UPA) provides the rules of how to determine the existence of a partnership.

${ }^{8}$ Guerin v The Queen [1984] 2 S.C.R. 335.

${ }^{9}$ Norberg $v$ Wynrib [1992] 2 S.C.R. 226.

10 There is similarity between the general partnership and the Hungarian "közkereseti társaság."

11 UPA (1958) §6. 
The Act declares that every partner is an agent of the partnership. ${ }^{12}$ Every partner must account to the partnership for any benefit and hold as trustee for any profit derived by him without the consent of the other partners from any transaction connected with the formation, conduct or liquidation of the partnership or from any use of its property by them. ${ }^{13}$ This is the only provision in the Uniform Partnership Act that refers to a partner's fiduciary duty. An ABA Committee commenting this section stated that while this rule is often cited as establishing a broad fiduciary duty, in fact, it is basically merely an anti-theft provision. ${ }^{14}$

Every member of the partnership can be an agent of the partnership, which means they are fiduciarily liable to each other. To understand this, I would like to briefly introduce the most famous case dealing with fiduciary duties, that of Meinhard $v$ Salmon. ${ }^{15}$ The case is very important to understand for two reasons: many partnership cases cite Meinhard as establishing a broad fiduciary duty between partners; and Benjamin Cardozo was the judge in this case, who described the relationship between the partners as: "A trustee is held to something stricter than the morals of the market place. Not honesty alone, but the punctilio of an honor ${ }^{16}$ the most sensitive, is then the standard of behavior... the level of conduct for fiduciaries [has] been kept at a level higher than that trodden by the crowd." "17

In 1902, Salmon bought a 20-year lease for the Hotel Bristol, owned by Elbridge Thomas Gerry on $5^{\text {th }}$ Avenue and $42^{\text {nd }}$ Street in New York. Salmon wished to convert the hotel into shops and offices. To raise money, he entered a joint venture with Meinhard. They put the terms of their relationship in writing. Meinhard provided the investment capital while Salmon managed the business. Meinhard was given the sole power to assign the lease during the term of the venture. The venture was created to terminate at the end of the lease.

After 20 years, as the lease was expiring and the joint venture coming to an end, the owner of the reversion of the lease, Gerry, approached Salmon to negotiate a substantial redevelopment of the property. Gerry was ignorant of the partnership. Salmon resigned the lease in his individual capacity without telling Meinhard. When Meinhard found out, he sued. Meinhard argued that the new opportunity belonged to the joint venture and sued to have the lease transferred to a constructive trust. Salmon argued that any interest in the new lease could not belong to the joint venture, since both parties expected the venture to terminate when the first lease expired. Meinhard claimed that his former business partner, Salmon, had violated a fiduciary duty by taking an opportunity to renew a lease in his own name without sharing the benefits.

12 UPA $\$ 9$.

13 UPA $\$ 21$.

${ }^{14}$ Robert W. Hamilton, Jonathan R. Macey and Douglas K. Moll, Cases and Materials on Corporations Including Partnerships and Limited Liability Companies (11th edn, Thomson Reuters 2010) 82.

${ }^{15}$ Meinhard v Salmon [1928] 249 N.Y. 458, 164 N.E. 545.

${ }^{16}$ Punctilio of honor means the highest standard of honor. It is a term used to describe the level of care that a fiduciary must abide by in his/her conduct to an individual or firm with whom s/he has a fiduciary relationship. The elements of punctilio are loyalty, honesty and good faith.

${ }_{17}$ Cardozo has many famous decisions such as Berkey $v$ Third Avenue Railway, the leader case in piercing the corporate veil. 
The court held that Salmon was an agent for the joint venture and determined the new business opportunity - which was made available to Salmon during the course of his agency or management of the venture - so Salmon was obligated to act as a fiduciary of the venture in the transaction. The court held that Salmon was obligated by the fiduciary duty of communication to notify the venture of profits obtained during the course of his agency. He was obligated by the duty of loyalty to share the profits with the venture, and he was required to inform Meinhard of the opportunity and allow him the possibility to compete for the lease.

This could be an instructive case for us too. In Hungary there is no legal relationship between the partners of the business association, just between a partner and the association. For example, when a partner takes a non-cash capital contribution of a higher value than its real value in a company, it causes damage to the company, and can violate the creditor's interests. In this case, the company has the power to sue its partner for the false value of the assets, but the partners have no right to sue him, and the court will reject the claim. ${ }^{18}$ Establishing a fiduciary relationship between the partners may be a solution to this problem.

\section{Can a former partner in a firm claim that the other partners violated the fiduciary duty to the former partner by negligent management?}

This question was raised in Bane $v$ Ferguson. ${ }^{19}$ Charles Bane was a lawyer who retired. He was a partner of a Chicago law firm. In August 1985 the firm adopted a retirement plan that entitled every retiring partner to a pension. Shortly after Bane's retirement, this law firm merged with another, but the merger was unsuccessful, and the firm dissolved. Bane was left without a pension. Bane brought an action of negligent management against the partners of the now dissolved firm. He argued that the defendants had a duty of care (fiduciary duty) to him as he is a former partner.

Here the question was whether a retired partner in the law firm had a common law or a statutory claim against the firm's managing council for acts of negligence that, by causing the firm to dissolve, terminated his retirement benefits.

The court rejected Bane's breach of fiduciary duty claim. The court said that the partner was a fiduciary of his partners, but not of his former partners, for the withdrawal of a partner terminates the partnership with regards to him. "Since Bane has stated that he is no longer a partner, and since he was not a partner at the time Isham wound up its affairs in April 1988, the defendants did not owe him a fiduciary duty under Illinois partnership law." 20

\footnotetext{
${ }_{18}$ Hungarian Civil Code § 3:99(2); Hungarian Supreme Court, Bf. III. 2103/1995.

${ }^{19}$ Bane v Ferguson [1989] Seventh Circuit Court of Appeals 890 F.2d 11.

${ }^{20}$ Hamilton, Macey and Moll (n 14) 90.
} 


\section{UPA or RUPA?}

The Uniform Partnership Act from 1914 (UPA) touches sparingly on a partner's duty of loyalty and leaves any further development of the fiduciary duties of partners to the common law of agency. With the exception of Louisiana, this Uniform Partnership Act was adopted in every state of America. In 1997 the UPA was revised, and this new act is called Revised Uniform Partnership Act (RUPA). The most recent revised edition has been enacted into law by 37 states. The RUPA handles a lot of things (e.g. the fiduciary duty) very differently than UPA, and regulates the most relevant elements of this liability form.

The RUPA says "the only fiduciary duties a partner owes to the partnership and to other partners are the duty of loyalty and the duty of care." ${ }^{21}$ It declares what the content of these duties includes (I elaborate on it in the next chapter). It is important that there are some commercially essential states such as New York, where the UPA is still in force, and there are far more UPA cases, so at the universities students study both UPA and RUPA.

RUPA is structurally different from UPA. UPA touches only sparingly on a partner's duty of loyalty and leaves further development of the fiduciary duties of partners to the common law of agency. In RUPA the basic elements of the fiduciary duty are clearly stated. Those rules are exclusive and encompass the entire duty of loyalty. ${ }^{22}$

And to introduce all perspectives, there are some authors who would have not described partners of the partnerships as fiduciaries. RUPA also includes the word fiduciary, although the Drafting Committee was repeatedly urged to strike it. It was said that a partner is not a fiduciary in the same strict sense as a trustee. A trustee is a person who acts solely on behalf of a beneficiary, while a partner is a co-owner of the partnership, who acts on behalf of the partnership and for his own interest as well. The Drafting Committee retained the word fiduciary because it found no reason to abandon the traditional notion that the partners are fiduciaries. ${ }^{23}$

\section{What are the basic elements of the fiduciary duty?}

The UPA was silent on the fiduciary duty, implicitly deferring to the common law of agency and to the case law derived therefrom. In 1988, in the Rosenthal $v$ Rosenthal case, the Supreme Court of Maine said that partners are subject to an ordinarily prudent person's standard. ${ }^{24}$ In this case the court listed four specific fiduciary duties owed by the business associates to each other:

(1) To act with that degree of diligence, care and skill which ordinarily prudent persons would exercise under similar circumstances in like positions;

\footnotetext{
${ }^{21}$ RUPA (1997) § 404.

22 Comment on the Revised Uniform Partnership Act § 404.

${ }^{23}$ Donald J. Weidner, 'Three Policy Decisions Animate Revision of Uniform Partnership Act' (1991) Bus. Law 427,459

24 ibid 465.
} 
(2) To discharge the duties affecting their relationship in good faith with a view to furthering the interests of one another as to the matters within the scope of the relationship;

(3) To disclose and not withhold from one another relevant information affecting the status and affairs of the relationship;

(4) To not use their position, influence or knowledge respecting the affairs and organization that are subject to the relationship to gain any special privilege or advantage over the other person or persons involved in the relationship. ${ }^{25}$

This case is very important for several reasons. The Rosenthal case retains the word fiduciary like the later RUPA. It uses it as an ordinarily prudent person standard. And, like the later RUPA, it defines fiduciary duties of partners in both entity and aggregate terms: a partner's duties include not only furthering the interest of the business enterprise but also furthering the interest of one another. ${ }^{26}$

The UPA Revision Subcommittee recommended that "[t]he fiduciary duties of partners to each other and the partnership should be made more explicit, similar to the formulation in the 1984 Model Business Corporation Act." With regard to UPA § 21 , the provision outlining the fiduciary duties of partners, the Subcommittee recommended that it "be revised to incorporate the full range of fiduciary duties developed by the cases (due care, good faith, loyalty, and full disclosure of all material facts)."

The more important difference between UPA and RUPA is that there is no statutory duty of care under UPA, and that any duty recognized by the courts is based on common law. All such common law standards are preempted by RUPA. ${ }^{27}$

RUPA declares explicitly that the fiduciary duty has two basic elements: the duty of loyalty and the duty of care. ${ }^{28} \mathrm{~A}$ partner's duty of loyalty to the partnership and the other partners is limited to the following: to be accountable to the partnership and hold as trustee for it any property, profit, or benefit derived by the partner in the conduct and winding up of the partnership business or derived from use by the partner of partnership property, including the appropriation of a partnership opportunity; to refrain from dealing with the partnership in the conduct or winding up of the partnership business as or on behalf of a party having an interest adverse to the partnership; and to refrain from competing with the partnership in the conduct of the partnership business before the dissolution of the partnership. ${ }^{29}$

These duties may not be waived or eliminated in the partnership agreement, but the agreement may identify activities and determine standards for measuring the performance of the duties, if not unreasonable. This express reference to the duty of loyalty is new but contains the case law. It is essential that until UPA leaves the

${ }^{25}$ Rosenthal $v$ Rosenthal [1988] 543 A.2d 348.

${ }^{26}$ Weidner (n 23) 466.

${ }^{27}$ Gerard C. Martin, 'Duties of Care under the Revised Uniform Partnership Act' (1998) U. Chi. L. Rev. 1307 (doi: 10.2307/1600265).

${ }^{28}$ There is some debate about whether the duty of care is a fiduciary obligation at all. When fiduciary duties are listed it is traditionally included, but many scholars question this characterization of the duty of care. They say that the duty to act with the minimum standard of skill, judgement, competence is not necessarily fiduciary and is found in many non-fiduciary relationships. Kelli Alces Williams (n 2) 244.

${ }^{29}$ RUPA (1997) § 404(b). 
judges to interpret the duty of loyalty, and has a very colorful case law background, RUPA provides three specific rules that comprise a partner's duty of loyalty. These merely codify the case law.

UPA imposes the fiduciary duty on partners to account for profits and benefits in all transactions connected with the formation, conduct, or liquidation of the partnership..$^{30}$ The formation of the partnership has been eliminated by RUPA, so the partners have no fiduciary duty in the pre-formation period. The comment of RUPA says that the duty of loyalty could be inappropriately extended to the pre-formation period when the parties are really negotiating at arm's length. Once a partnership is agreed to be established, each partner becomes a fiduciary in the conduct of the business. The pre-formation deals, negotiations will be subject to the general contract obligation. ${ }^{31}$ I think the removal of the pre-formation period from the liability rules was a good solution.

RUPA says about the duty of care that "a partner's duty of care to the partnership and to the other partners in the conduct and winding up of the partnership business is limited to refraining from engaging in grossly negligent or reckless conduct, intentional misconduct, or a knowing violation of law."32

Though there was no statutory provisions for the duty of care in the UPA, there were some cases where the courts referred to it. For example, this occurred in the Bane $v$ Ferguson case, which I have already mentioned above. ${ }^{33}$ Charles Bane sued the law company for breaching their duty of care through negligent mismanagement.

The question was whether the defendants violated a duty of care to the plaintiff founded on general principles of tort law. There is

"no precedent in Illinois law or elsewhere for imposing tort liability on careless managers for the financial consequences of the collapse of the firm to all who are hurt by that collapse... If the dissolution is motivated by good faith judgement for the benefit of the corporation rather than personal gain of the officers, directors or shareholders, no liability attaches to the dissolution." ${ }^{4}$

\title{
7. Should partners be allowed to limit or eliminate fiduciary duties by contract (partnership agreement)?
}

\author{
According to RUPA,
}

"The partnership agreement may not eliminate the duty of loyalty but the partnership agreement may identify specific types or categories that do not violate the duty of loyalty if not manifestly unreasonable. All of the partners or a number or percentage specified in the partnership agreement may authorize or ratify, after full disclosure

\footnotetext{
30 UPA (1914) § 21.

31 Comment on the Revised Uniform Partnership Act § 404.

32 RUPA (1997) § 404(c).

${ }^{33}$ Bane (n 19).

${ }^{34}$ Hamilton, Macey and Moll (n 14) 91.
} 
of all material facts, a specific act or transaction that otherwise would violate the duty of loyalty. The partnership agreement may not unreasonably reduce the duty of care." 35

What does "the limitation should not be 'unreasonable"' mean?

The relations between the partners and between the partners and the partnership are governed by the partnership agreement. These sections of RUPA are mandatory rules, which means the partners in the agreement are allowed to agree in other ways than contained in the RUPA. So, these statute rules can be modified by the partners in the partnership agreement. These rules should not be manifestly unreasonable. On the other hand, the courts have to decide in concrete cases whether such a limit of fiduciary duty in the partnership agreement is valid or not.

The most relevant case here, that everybody refers to, is the Singer $v$ Singer case ${ }^{36}$ where the partners declared a liability limitation in the partnership agreement. The Singer family formed Josaline Production Co., an oil production partnership in the late 1930s. The interests became inherited and assigned down through the family, fractionalizing ownership. They declared in the agreement that "each partner shall be free to enter into business and other transactions for his or her own separate individual account, even though such business or other transaction may be in conflict with and/or competition with the business of this partnership...137 In 1979 the Josaline partnership held a meeting where one of the investments discussed was purchasing 95 acres for $\$ 1.5$ million, but the decision was deferred. Before the meeting, Joe Singer requested one of the defendants (Stanley) to look into the possibility of purchasing it. After the meeting, Stanley and Andrea (defendants) formed a general partnership named Gemini and purchased the land in Gemini's name. When Joe learnt about it he demanded that Singer Bros. (his own partnership that was a partner of Josaline) be permitted to purchase $50 \%$ of the property. Stanley and Andrea (defendants) offered to give $16.66 \%$ but withdrew it before it had been accepted. Joe then brought a suit.

The court said that the defendants had a contractual right to do what they did, namely, compete with the partners of Josaline and with Josaline itself as if there never had been a partnership. It means that partners and members of business associations can contract away many fiduciary duties imposed by the law. ${ }^{38}$ There are limitations on what can be contracted away on a state-by-state basis. Most relevant is Delaware, that will not allow for partnerships to contract away liability for bad faith violations of the implied contractual covenant of good faith and fair dealing. ${ }^{39}$

${ }^{35}$ RUPA § 103.

${ }^{36}$ Singer v Singer [1981] OK CIV APP 43634 P.2d 766.

37 "Neither the partnership nor any individual member of this partnership shall be entitled to claim or receive any part of or interest in such transactions, it being the intention and agreement that any partner will be free to deal on his or her own account to the same extent and with the same force and effect as if he or she were not and never had been members of this partnership."

${ }^{38}$ Another similar case is Singer $v$ Scher, where there was an oral agreement that permitted law partners to keep profits from investment opportunities derived from clients. Singer ( $\mathrm{n} 36$ ).

${ }^{39}$ Delaware Revised Uniform Limited Partnership Act $\$ 17.1101$ (c) It is the policy of this chapter to give maximum effect to the principle of freedom of contract and to the enforceability of partnership agreements. (d) 


\section{Summary}

It is very hard to understand a legal institution like fiduciary duty in the US legal system with a "continental legal mind". But the harder it is, the more interesting it gets. I hope that this article could bring the reader closer to this institution.

The fiduciary duty requires the fiduciary to get in the best interests of the beneficiary in a manner characterized by trust, confidence, loyalty, and an avoidance of conflict of interest. In the US and Canadian Supreme Court cases it is clear that failure to meet any of these strict standards of fiduciary conduct is a breach of the fiduciary duty which will give rise to a remedy. ${ }^{40}$

As the costs and benefits of fiduciary duties vary from firm to firm, these duties must vary in order to suit the particular relationships. The parties themselves are in a better position than courts to determine precisely what level of duties should apply to their relationship.

I tried to present the development and the basic elements of the fiduciary duty in the field of general partnerships. We could see that the contractual limitation of this liability form exists, but it is handled very differently, state by state.

To the extent that, at law or in equity, a partner has duties (including fiduciary duties) and liabilities relating thereto to a limited partnership or to another partner, (1) any such partner acting under a partnership agreement shall not be liable to the limited partnership or to any such other partner for the partner's good faith reliance on the provisions of such partnership agreement, and (2) the partner's duties and liabilities may be expanded or restricted by provisions in a partnership agreement.

${ }^{40}$ Parfitt and Munro (n 4). 